\title{
PEMBERDAYAAN MASYARAKAT MELALUI WISATA EDUKASI DAN DAMPAK YANG DIDAPATKAN MASYARAKAT DESA PUJONKIDUL
}

\section{Community Empowerment ThroughEducational Tourism and The Impact of Pujonkidul Village Communities}

\author{
Yogi Hermawann ${ }^{1}$ Syarif Hidayatullah², Stella Alviana ${ }^{3}$, Dewi Hermin ${ }^{4}$, Aprilia \\ Rachmadian ${ }^{5}$
}

Universitas Merdeka Malang12345

Email: yogihermawan042@gmail.com ${ }^{1}$

Email: syarif_ok@yahoo.com²

Email: stella.alvianna@unmer.ac.id ${ }^{3}$

\begin{tabular}{l|l|l}
\hline DOI: https://doi.org/10.53754/edusia.v1i1.21 & \\
\hline Received: 2021-07-05 & Revised: 2021-07-30 & Approved: 2021-07-31 \\
\hline
\end{tabular}

\begin{abstract}
Educational tourism is a type of travel that aims to provide an overview, comparative research or knowledge of the field visited-this article made for study community empowerment through educational tourism and the impact of the Pujonkidul village community. Research conducted using a qualitative approach, namely research methods that go directly to the field to find data and the data obtained is the result of interviews and documentation. Stage's analysis data that used researcher in research this is as following; collection data, Data reduction, Data presentation, and withdrawal conclusion. The results obtained from this study are that with the community empowerment program through educational tourism, the local community has a positive impact, especially in terms of the economy.
\end{abstract}

Keyword: Tourism, educational tourism, village development, community empowerment

\begin{abstract}
Abstrak: Wisata edukasi merupakan jenis perjalanan wisata yang bertujuan untuk memberikan gambaran atau pengetahuan bidang wisata yang dikunjunginya. Jurnal ini dibuat untuk mengkaji pemberdayaan masyarakat melalui wisata edukasi dan dampak yang didapatkan masyarakat desa Pujonkidul. penelitian yang dilakukan menggunakan metode pendekatan kualitatif yakni metode penelitian yang terjun langsung ke lapangan untuk mencari data dan data yang didapatkan merupakan hasil wawancara dan dokumentasi. Tahapan analisis data yang digunakan peneliti dalam penelitian ini adalah sebagai berikut; pengumpulan data, Reduksi data, Penyajian data, dan penarikan kesimpulan. Hasil yang didapat dari penelitian ini adalah dengan adanya program pemberdayaan masyarakat melalui wisata edukasi terdapat dampak positif yang didapatkan oleh masyarakat lokal. Terlebih dalam hal ekonomi.
\end{abstract}

Kata Kunci: Pariwisata, wisata edukasi, pengembangan desa, pemberdayaan masyarakat 


\section{PENDAHULUAN}

Indonesia merupakan suatu negara yang memiliki banyak potensi dari segi alam, seni, dan budaya. tidak dapat dipungkiri negara yang memiliki puluhan provinsi ini memiliki beragam keindahan alam yang dapat ditawarkan. Dengan dikembangkannya potensi alam di negeri ini akan membawa dampak positif bagi negara Indonesia, terlebih pada Industri Pariwisata. Dari ribuan keindahan alam yang dimiliki Indonesia kabupaten malang memiliki beberapa keindahan alam yang dijadikan sebagai objek wisata seperti gunung bromo, pantai balekambang, pantai teluk asmara dan masih banyak lagi. Namun kini dengan semakin berkembangnya jaman. Kini dalam pengembangan wisata banyak alternative yang dapat ditempuh. Salah satunya adalah dengan pengembangan suatu desa dan menjadikannya sebagai desa wisata.

Mengutip dari Trisnawati et al., ${ }^{1}$ desa wisata adalah pengelolaan suatu desa yang dilakukan oleh masyarakat yang terdiri dari para penduduk desa yang memiliki kepedulian serta kesadaran akan potensi alam dan bekerja sama dalam penyatuan atraksi, akomodasi, dan fasilitas yang disajikan dalam suatu struktur kehidupan masyarakat sehingga berkembang menjadi sebuah wisata dengan menerapkan sapta pesona.

Salah satu Desa Wisata yang cukup dikenal oleh masyarakat baik dalam lingkup daerah maupun luar daerah adalah Desa Wisata Pujonkidul. Desa Wisata Pujonkidul merupakan Desa yang berlokasi di Kecamatan Pujon Kabupaten Malang Provinsi Jawa timur, Desa ini berhasil mengembangkan potensi alam yang di milikinya dan diresmikan sebagai Desa Wisata pada tanggal 6 Agustus 2016. Dalam hal ini desa harus memperkenalkan potensi-potensi yang dimiliki desa meliputi kelebihan dan kelemahan juga ciri khas dari desa tersebut, sehingga mampu menjadi daya tarik dari desa tersebut. Alam Desa Pujonkidul sangat mendukung untuk dijadikan destinasi wisata yang bisa mendatangkan wisatawan, dengan menawarkan keindahan pemandangan alam di area persawahan hijau dan kesederhanaan pola hidup masyarakat sebagai daya tarik wisata.hal ini akan berdampak pada meningkatnya perekonomin desa sehingga merubah kesejahteraan masyarakat desa untuk menjadi lebih baik.

Dalam pelaksanaan pengembangan desa wisata, masyarakat lokal akan diikut sertakan dalam pembangunannya. Upaya tersebut merupakan langkah efektif pemerintah desa untuk memberdayakan masyarakatnya dengan meningkatkan kreatifitas warga sehingga dapat meningkatkan perekonomian masyarakat itu

1 Aditya Eka Trisnawati, Hari Wahyono, and Cipto Wardoyo, "Pengembangan Desa Wisata Dan Pemberdayaan Masyarakat Berbasis Potensi Lokal," Jurnal Pendidikan: Teori, Penelitian, Dan Pengembangan; Vol 3, No 1: JANUARI 2018DO - 10.17977/Jptpp.V3i1.10356 , January 1, 2018, http:/ /journal.um.ac.id/index.php/jptpp/article/view/10356. 
sendiri. menurut Gunawan Sumodiningrat sebagaimana dikutip oleh Mulyadi2 pemberdayaan masyarakat merupakan cara memandirikan masyarakat untuk menentukan potensi diri yang paling sesuai dengan kemampuan yang dimiliki untuk memajukan diri masing-masing. Ayu Purnami Wulandari dalam penelitiannya mengemukakan bahwa pemberdayaan masyarakat yang terlaksana dengan baik dapat membantu meningkatkan kesejahteraan masyarakat desa. ${ }^{3}$

Edukasi atau pendidikan adalah usaha sadar dan terencana untuk mencapai Suasana belajar dan proses pembelajaran membuat siswa proaktif Untuk mengembangkan potensi kekuatan spiritual keagamaan, Kontrol diri, kepribadian, kecerdasan, dan keterampilan yang diperlukan Terdaftar. Wisata edukasi sendiri merupakan salah satu jenis wisata minat khusus Diklasifikasikan menurut motivasi tertentu, biasanya berkaitan dengan waktu dan hobi Dan mengejar waktu luang, inilah kombinasi hiburan dan pendidikan. Wisata edukasi adalah jenis perjalanan wisata yang bertujuan untuk Memberikan gambaran, penelitian komparatif atau pengetahuan Bidang pekerjaan yang dikunjunginya. Jenis perjalanan ini juga disebut perjalanan studi atau perjalanan akses pengetahuan. ${ }^{4}$

Tujuan dilakukan penelitian ini ialah untuk mengkaji proses pemberdayaan masyarakat melalui wisata edukasi dan dampak yang didapatkannya. beberapa rumusan masalah dalam penelitian adalah sebagai berikut: 1) Bagaimana Proses Pengembangan Desa wisata Pujonkidul? 2). bentuk partisipasi apa saja yang diikuti oleh masyarakat pujonkidul? 3). Apakah ada dampak positif dengan adanya pemberdayaan masyarakat melalui wisata edukasi?

\footnotetext{
2 Mohammad Mulyadi, "PERAN PEMERINTAH DALAM MENGATASI PENGANGGURAN DAN KEMISKINAN DALAM MASYARAKAT," Jurnal Kajian 21, no. 3 (2016), https://doi.org/https://doi.org/10.22212/kajian.v21i3.776.

3 Ayu Purnami Wulandari, "Pemberdayaan Masyarakat Desa Dalam Upaya Peningkatan Kesejahteraan Keluarga Melalui Pelatihan Pembuatan Sapu Gelagah Di Desa Kajongan Kecamatan Bojongsari Kabupaten Purbalingga" (Universitas Negeri Yogyakarta, 2015).

4 Gamal Suwantoro, Dasar-Dasar Pariwisata (Jakarta: ANDI, 2004), https://onesearch.id/Record/IOS7783.ai:slims-5288.
} 


\section{METODE}

Peneliti menggunakan pendekatan kualitatif sebagai metode penelitian dalam penelitian ini. Yakni data yang terkumpul merupakan data yang berasal dari naskah wawancara bukan dalam bentuk angka-angka seperti metode kuantitatif. Penelitian kualitatif adalah jenis penelitian yang bertujuan untuk memahami fenomena (seperti perilaku, persepsi, motivasi, tindakan) yang dialami oleh objek penelitian. ${ }^{5}$ Fenomena tersebut diintegrasikan melalui deskripsi kata dan bentuk bahasa di bawahnya. keadaan. Pahami. Adalah wajar untuk menggunakan berbagai metode ilmiah.Metode ini membantu peneliti dalam penelitian terkait proses pemberdayaan masyarakat melalui wisata edukasi dan dampak yang didapatkan masyarakat desa.

Pendekatan merupakan proses yang dilakukan dalam hal mendekati sesuatu, jika dikaitkan dengan pendekatan, pemberdayaan (the empowerment approach) merupakan pendekatan dengan memberikan pengalaman atau pelatihan kepada masyarakat guna mengatas ketidakberdayaan terlebih pada bidang ekonomi akibat kemiskinan. Sedangkan Pendekatan pelatihan merupakan titik tolak atau sudut pandang terhadap suatu proses pelatihan.pandangan tentang terjadinya proses yang bersifat umum. Beberapa macam pendekatan pelatihan antara lain; pendekatan kontekstual, kontruktivisme, deduktif, induktif, afektif, pedagogi, dan andragogi. Selanjutnya pendekatan Pendidikan merupakan suatu proses kegiatan, perbuatan, dan cara mendekati bidang pendidikan sehingga mempermudah pelaksanaan kegiatan pendidikan tersebut.

Lokasi penelitian dilakukan di Dusun Krajan Desa wisata Pujonkidul kecamatan Pujon Kabupaten Malang Provinsi Jawa timur dan waktu penelitian dimulai pada tanggal 6-12 Desember 2020.

Sumber data diperoleh melalui informan yang dianggap mampu menjawab seluruh daftar pertanyaan dan paham tentang latar belakang dan kondisi dari obyek yang diteliti untuk mendapatkan hasil yang lebih akurat. Berikut beberapa informan terpilih yang akan menjadi subyek dari penelitian:

Tabel 1. Nama dan Jabatan informan kunci wawancara

\begin{tabular}{lllll}
\hline $\mathbf{N o}$ & Nama & Jabatan & \\
\hline $\mathbf{1}$ & Udi Hartoko & Kepala Desa Wisata Pujonkidul & \\
\hline $\mathbf{2}$ & Sudirman & Sekretaris Desa Wisata Pujonkidul & \\
\hline $\mathbf{3}$ & Anas Taufiq & Bendahara Desa Wisata Pujonkidul & \\
\hline $\mathbf{4}$ & Moh Said & $\begin{array}{l}\text { Kepala seksi pemerintahan Desa Wisata } \\
\text { Pujonkidul }\end{array}$ & \\
\hline $\mathbf{5}$ & Hadi & Kepala Kelompok Sadar wisata Capung Alas \\
\hline $\mathbf{6}$ & 20 Responden & Masyarakat Desa \\
\hline
\end{tabular}

${ }^{5}$ Lexy J Moleong, Metodologi Penelitian Kualitatif, Ed. Revisi/ Moleong (Bandung: Remaja Rosdakarya, 2010). 
Data yang terkumpul kemudian di analisis untuk menghasilkan kesimpulan. Bogdan dan Tylor mengemukakan bahwa analisis data merupakan suatu proses merinci untuk menemukan hipotesis. ${ }^{6}$ Tahapan analisis data yang digunakan dalam penelitian ini yang pertama adalah pengumpulan data, data dikumpulkan melalui 25 responden yang merupakan 5 pemangku desa dan 20 masyarakat umum. Kemudian langkah selanjutnya adalah reduksi data yakni proses memilih atau menyederhanakan data kasar yang didapatkan pasa saat proses wawancara. Dilanjutkan dengan proses penyajian data yaitu informasi yang telah di reduksi disajikan atau ditampilkan secara tersusun untuk di lakukan penarikan kesimpulan. Dan langkah terakhir merupakan penarikan kesimpulan yakni penentuan hasil akhir yang didapatkan dari wawancara yang dilakukan.

\section{PEMBAHASAN}

\subsection{Desa Pujonkidul}

Desa Pujonkidul merupakan satu dari 11 desa yang berada dalam wilayah Kecamatan Pujon, Kabupaten Malang, Provinsi Jawa Timur. Secara geografis pujonkidul terletak pada posisi $7^{\circ} 21^{\prime}-7^{\circ} 31^{\prime}$ Lintang Selatan dan $110^{\circ} 10^{\prime}-111^{\circ} 40^{\prime}$ Bujur Timur, dengan Luas mencapai 330.000 hektar (Data Desa Pujonkidul, 2018) yang seluruh wilayahnya dikelilingi perbukitan. Berdasarkan data administrasi desa tahun 2013, jumlah Penduduk desa Pujonkidul mencapai 1.330 Kepala keluarga atau 4.167 jiwa, dengan rincian 2.066 laki-laki dan 2.101 perempuan. Wilayah Pujonkidul terbagi menjadi 3 Dusun yakni, Dusun Krajan, Dusun Maron, dan Dusun Tulungrejo yang setiap dusunnya dipimpin oleh kepala Dusun. Berbatasan dengan beberapa desa di wilayah kecamatan pujon seperti Desa Pujon lor disebelah Utara dan Timur, Desa Sukomulyo di sebelah barat dan Perhutani di sebelah selatan.

Letak Desa Pujonkidul berada diketinggian 1200m diatas permukaan air laut. Dengan curah hujan yang cukup rata-rata mencapai $2000 \mathrm{~mm} /$ tahun dan kontur tanah hitam yang subur, menjadikan roda perekonomian masyarakat rata rata hidup di sektor pertanian dan perkebunan rata-rata petani di daerah ini mengolah lahan untuk menanam palawija seperti sayur sayuran, jagung, tomat, wortel dan buah buahan seperti apel dan jeruk.

Suksesnya suatu desa tidak lepas dari peran pemerintah desa yang bekerja sama dalam mengemban tugasnya sebagai pengelola dari desa tersebut. Pemerintah Desa merupakan lembaga pemerintah yang mengemban tugas mengelola wilayah suatu desa. Saat ini Desa Pujonkidul dipimpin oleh Kepala Desa yang bernama Udi Hartoko yang mulai menjabat sejak tahun 2011 dan saat ini sedang memasuki

${ }^{6}$ Moleong, 280. 
periode kedua. Dalam mengemban tugasnya kepala desa di bantu oleh beberapa staff desa. Adapun struktur tersebut dapat dilihat pada table 2 dibawah ini.

Tabel 2. Struktur Pemerintah Desa Pujonkidul

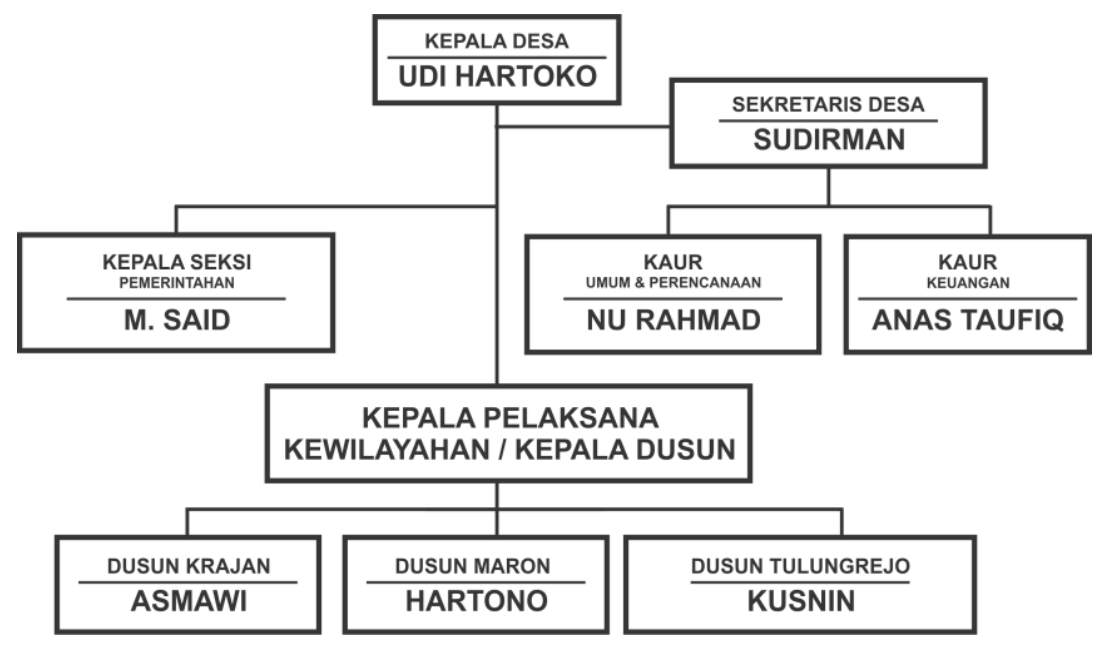

Sumber: Data administrasi desa ,2018

\subsection{Proses Pengembangan Desa Wisata Pujonkidul}

Pariwisata di desa ini mulai dikembangan pada tahun 2013 yakni pada saat beberapa kelompok masyarakat yang menyadari akan potensi desa yang menjadi cikal bakal dari kelompok Sadar wisata mengeksplorasi daya tarik wisata air Sumber pitu yang berada di Dusun Tulungrejo desa Pujonkidul. Mereka berharap dengan mengeksplorasi wisata ini dapat meningkatkan kehidupan ekonomi warga sekitar dikarenakan penghasilan dari pertanian kurang memadai. Upaya Eksplorasi wisata dilakukan dengan perbaikan akses jalan dan infrastuktur menuju wisata air terjun sumber pitu. Namun pada tahun 2014, Perhutani ikut serta dalam pengelolaan wisata ini. Dalam pelaksanaannya hal tersebut dirasa tidak berjalan sebagaimana mestinya. Karena tidak memihak masyarakat sekitar terlebih pada segi pendapatannya sehingga Pujonkidul menarik diri dari pengelolaan wisata ini (hasil wawancara dengan Kepala Pokdarwis Bapak Samsul Hadi, 10 Desember 2020)

Dengan pengalaman tersebut ditahun berikutnya Pokdarwis mengajak Masyarakat Lain untuk berpartisipasi dalam mengeksplor potensi yang ada di daerah ini dan mengembangkannya menjadi daya tarik wisata. Adapun beberapa bentuk partisipasi yang dilakukan masyakarakat adalah; partisipasi buah pikiran, merupakan bentuk partisipasi pendapat atau saran yang dapat digunakkan dalam proses pengembangan desa wisata partisipasi buah pikir di desa wisata pujonkidul diterapkan dengan dilibatkannya masyarakat pada saat pemanduan dan evaluasi setiap kegiatan. partisipasi tenaga fisik, keikutsertaan masyarakat yang melibatkan 
aktifitas fisik dalam pengaplikasiannya seperti gotong royong dalam pembangunan toilet umum, pemasangan rambu rambu jalan, pemasangan rambu wisata, juga pengecoran jalan di sekitar area atraksi wisata. partisipasi keahlian, masyarakat desa wisata Pujonkidul turut serta dalam menyumbangkan keahlian mereka seperti pembuatan batik, pengelolaan olahan oleh-oleh, dll. Masyarakat yang tidak aktif dalam beberapa bentuk partisipasi yang dijelaskan diatas dapat berpartisipasi melalui penerapan sapta pesona. Pengembangan atraksi wisata Desa Pujonkidul dilakukan dengan memanfaatkan potensi alam pedesaan banyak tempat disulap dan dipercantik namun tetap menjaga suasana pedesaan asli sebagai daya tarik wisata.

Hingga pada tanggal 10 Agustus 2016, Desa ini diresmikan oleh Bupati Malang pada masa itu dan menjadi Desa wisata Pujonkidul dengan Café sawah sebagai salah satu amenitas dan atraksi wisata yang ditawarkan. Café sawah yang memiliki view yang menarik dengan suasana yang segar nyaris tak pernah sepi pengunjung. Setiap harinya tidak kurang dari 300 pengunjung yang mendatangi wisata ini. Bahkan jika akhir pekan tiba atau masa liburan pengunjung yang datang dapat meningkat hingga 3000-5000 orang perharinya. Pada tahun berikutnya amenitas dan atraksi yang ditawarkan semakin beragam ada beberapa tambahan wahana seperti motocross, jeep, petik strawberry, wisata berkuda dan wahana air. Hanya dengan membayar retribusi sebesar Rp. 10.000,- di pintu masuk pengunjung sudah membayar parkir dan mendapat cashback yang dapat digunakan sebagai voucher makan di café sawah. Pengunjung hanya perlu membayar selisih dari voucher yang didapatkan. Dari nominal sebesar Rp.10.000,- tersebut pemasukan desa dapat digambarkan sebagai berikut.

Tabel 3. Gambaran Pendapatan desa wisata

\begin{tabular}{ll}
\hline Cetak kupon & Rp.1.000,- \\
\hline Biaya parkir R2/R4 & RP.1.500,- / Rp. 4.500,- \\
\hline Voucher makan & Rp. 5.000,- \\
\hline Kontribusi makanan & Rp. 2,500,- \\
\hline Pendapatan Desa & $20 \%$ dari Rp. 2.500,- \\
\hline
\end{tabular}

(data didapatkan dari wawancara dengan Bendahara Desa Bapak Anas Taufiq)

Selain Café Sawah Beberapa ada beberapa atraksi wisata yang ditawarkan Desa wisata ini guna menarik minat pengunjung. Adapun atraksi wisata tersebut adalah sebagai berikut:

Live In (Tinggal bersama): Live in merupakan paket wisata edukasi Desa wisata Pujonkidul. Paket yang ditawarkan adalah wisata edukasi pertanian, peternakan, UMKM, dan keterampilan. Target pemasaran dari paket wisata Live in biassanya merupakan Keluarga, sekolah, instansi perusahaan atau kelompok yang 
ingin menikmati liburan di desa wisata Pujonkidul untuk waktu yang lama. Wisata yang mengambil paket wisata ini diajak untuk mengikuti program Live in dengan tinggal bersama dengan warga desa dan melakukan beragam kegiatan yang sudah dijadwalkan. Beberapa kegiatan tersebut diantaranya edukasi pertanian yang biasanya dilakukan pada pagi hari pengunjung diajarkan bagaimana cara menanam sayuran, mencangkul hingga memetik sayuran, kemudian edukasi peternakan biasanya dilakukan pada jam jam yang sudah ditentukan pengunjung diajarkan bagaimana cara memerah dan merawat sapi milik warga setempat. Sedangkan edukasi UMKM pengunjung akan belajar bagaimana mengolah susu dan sayur mayur menjadi produk makanan atau camilan yang dapat dipasarkan. Juga edukasi keterampilan biasanya pengunjung akan diajarkan membuat kreasi keterampilan seperti membatik dan membuat topeng.

Kirab Budaya: Kirab Budaya merupakan event tahunan yang diadakan dalam rangka memperingati bersih Desa wisata Pujonkidul. Masyarakat desa diajak ikut berpartisipasi dalam kegiatan ini. Biasanya setiap rukun tetangga menampilkan kreatifitas dengan tema yang berbeda dan berjalan mengikuti rute yang sudah ditentukan.

Festival Ublik: Festival Ublik merupakan festival tahunan yang diadakan pada malam hari, masyarakat sekitar akan bejualan menu menu tradisional dengan tatanan tempo dulu. Biasanya diadakan selama 3 hari berturut-turut dan bertepatan dengan Hari Ulang tahun Desa wisata Pujonkidul.

Taman Budaya: Taman budaya merupakan atraksi wisata yang memiliki taman bunga, amphiteather biasanya digunakan untuk menggelar acara pentas seni dan budaya.

Bukit Nirwana: Bukit nirwana merupakan atraksi wisata yang terbilang baru yang ada di Desa wisata Pujonkidul. Wisata ini berada di kawasan perbukitan Dusun tulungrejo. Atraksi yang ditawarkan adalah swafoto dengan pemandangan desa wisata pujonkidul dari perbukitan.

\subsection{Wisata Edukasi Sebagai Program Pemberdayaan Masyarakat}

Perkembangan desa wisata Pujonkidul yang begitu pesat membawa dampak positif bagi masyarakat setempat terutama dalam penyerapan tenaga kerja. Setidaknya kurang lebih 2.000 anggota masyarakat atau hampir 50\% dari penduduk desa dilibatkan dalam Pengelolaan desa wisata ini. Hal ini merupakan bukti dari partisipasi masyarakat dan tercapainya tujuan utama dari pokdarwis yakni memberdayakan masyarakat desa wisata Pujonkidul. Penyerapan tenaga kerja pada sektor wisata ini begitu banyak. banyak masyarakat dari semua kalangan baik remaja sampai orang tua bekerja dan ikut serta menyukseskan program wisata Pujonkidul. Ada yang bekerja sebagai pemandu wisata, juru parkir, tukang masak, 
joki kuda, pekerja di wahana sekitar hingga berjualan di kedai kedai kuliner sekitar café sawah.

Pada Proses Pemberdayaan Masyarakat Desa Pemerintah desa wisata Pujonkidul berupaya menghidupkan Kegiatan Usaha masyarakatnya dengan mengadakan program pemberdayaan masyarakat, berikut beberapa program yang diterapkan di desa wisata Pujonkidul;

Tabel 3. Program Pemberdayaan Masyarakat Desa Pujonkidul

\begin{tabular}{|c|c|c|}
\hline No & $\begin{array}{l}\text { Nama Program } \\
\text { Pemberdavaan }\end{array}$ & Keterangan \\
\hline 1. & Bantuan Tunai RT & $\begin{array}{l}\text { Desa wisata Pujonkidul memberikan Bantuan tunai } \\
\text { sebesar Rp. 10.000.000.00 (sepuluh juta rupiah) pada } \\
\text { masing masing RT. Dana tersebut nantinya akan } \\
\text { dikembangkan oleh lingkup RT tersebut untuk } \\
\text { memberdayakan masyarakatnya ada yang menggunakan } \\
\text { dana sebagai modal usaha penjualan Tabung Gas, } \\
\text { Sembako dll. }\end{array}$ \\
\hline 2. & Homestay & $\begin{array}{l}\text { Homestay disini ditujukan untuk para pengunjung yang } \\
\text { ingin menikmati program live in. yakni tinggal bersama } \\
\text { penduduk desa dan belajar edukasi, bagi masyarakat yang } \\
\text { memiliki rumah dengan ruang kamar kosong dapat } \\
\text { menawarkannya sebagai fasilitas akomodasi. Hingga saat } \\
\text { ini menurut data administrasi desa terdapat } 65 \text { kamar yang } \\
\text { sesuai denan standar SOP dan } 27 \text { kamar tanpa SOP. }\end{array}$ \\
\hline
\end{tabular}

3. Edukasi Peternakan dengan memanfaatkan usaha masyarakat yang notabene menjadi peternak sapi. Pemerintah desa memanfaatkan lahan tersebut sebagai ladang usaha. Kandang kandang milik masyarakat akan disewakan kepada desa dan dijadikan tempat untuk edukasi peternakan yang ditawarkan oleh atraksi wisata edukasi live in. biasanya dalam mengedukasi pemilik kandang juga diajak ikut serta dalam mengedukasi wisatawan yang berkunjung.

4. Edukasi Pertanian sama hal nya dengan edukasi peternakan, edukasi pertanian juga menyewa beberapa petak lahan persawahan milik masyarakat dan digunakan untuk edukasi pertanian untuk wisatawan yang ingin belajar bercocok tanam.

5. Edukasi Kesenian Edukasi Kesenian berempat di dusun tulungrejo pemerintah mengajak masyarakat sekitar untuk ikut serta dalam menangani wisatawan, masyarakat di ajarkan bagimana cara membuat topeng dan membantik lalu menerapkannya pada wisatawan yang ingin mempelajari kesenian batik dan topeng.

6. Home Industry Home Industry atau industri rumahan kelompok




masyarakat memiliki tanggung jawab mengelola
pengolahan komoditas desa. meliputi olahan susu sapi,
olahan sayur dan oalahan buah. Olahan ini nantinya akan
di jual ke pasar maupun wisatawan yang berkunjung ke
desa wisata pujonkidul. Selain membuat olahan untuk
komoditas desa. Indutri ini juga menerima para wisatawan
yang ingin beredukasi UMKM.

Berdasarkan tabel diatas dapat dilihat program pemberdayaan masyarakat yang ada di Desa Pujonkidul lebih menitikberatkan pada wisata edukasi seperti edukasi pertanian, peternakan, dan edukasi UMKM. Hal ini dimaksudkan karena Desa Pujonkidul memiliki banyak kegiatan yang berpotensi untuk dipelajari oleh masyarakat luar. Hal ini dikarenakan banyaknya sumber sumber edukasi yang mana mampu menjadikan wisatawan yang berkunjung dapat mendapatkan pengalaman wisata edukasi. Selain wisata edukasi yang disebutkan di atas wisatawan dapat mendapatkan pengalaman bersosial bersama masyarakat Desa yang notabene memiliki sikap ramah tamah terhadap sesame.

Wawancara yang dilakukan kepada 5 informan kunci dan 20 informan pendukung yang pada prinsipnya untuk menggali data tentang Proses pemberdayaan masyarakat melalui wisata edukasi di desa wisata pujon kidul. Wawancara mendalam ini dilakukan dengan maksud menjawab pertanyaan peneliti, yakni; a) bagaimana proses pembentukan desa pujonkidul menjadi desa wisata? b) Apa saja Program pemberdayaan masyarakat desa yang diberikan pemerintah desa wisata pujonkidul? c) dampak yang didapatkan masyarakat desa wisata pujonkidul? hasil yang didapatkan dari wawancara proses pemberdayaan masyarakat di Desa Wisata Pujon Kidul diperoleh hasil sebagai berikut:

Dengan adanya pemberdayaan masyarakat desa dan dengan dengan di bentuknya café sawah program pemberdayaan masyarakat desa mulai berjalan. Pemuda pemudi dengan pendidikan yang minim dan pengangguran mendapatkan lowongan pekerjaan. Kenaikan ekonomi desa pun tidak bisa di hindari. Tidak berpuas sampai disitu Podarwis mengajak Masyarakat Desa untuk lebih kreatif dan Produktif dengan mengembangkan Program Pemberdayaan Masyarakat desa.

Dalam pengaplikasiannya tidak semudah apa yang di harapkan. banyak masyarakat yang tidak paham dan tidak ikut serta dalam program pemberdayaan. Namun dengan mengedukasi masyarakat bahwa dengan mengikuti program program ini dapat meningkatkan ekonomi dan mengajak masyarakat untuk ikut berpartisipasi menyuarakan buah fikirnya pada saat rapat bulanan atau tahunan untuk pengembangan desa diharapkan mampu membut kepercayaan masyarakat pada program pemberdayaan ini. Walaupun belum semua namun hingga saat ini 
hampir seluruh masyarakat lokal ikut serta dalam program pemberdayaan dan berpartisipasi dalam pengembangan desa wisata.

Selanjutnya informan masyarat yang terlibat dari 20 Responden yang berasal dari masyarakat Lokal saat dilakukan wawancara secara terpisah 20 responden memiliki jawaban yang serupa, seperti yang diterangkan Beberapa responden;

\section{Responden 1. Bapak Amin (Ojek Wisata):}

"Dulu sebelum adanya Café sawah, saya hanya mengandalkan hasil pertanian yang kadang naik kadang juga merosot mengikuti pasar. Satu satunya sumber Ekonomi saya adalah dengan bercocok tanam. Namun kini saya terbantu dengan adanya café sawah, saya bisa menjadi ojek wisata di sela sela waktu saya bercocok tanam. Dan tentunya Ekonomi keluarga saya naik"

\section{Responden 2. Ibu Muji (Pemilik Warung):}

"Selain bertani, saya juga membuka warung klontong dirumah, untuk membantu suami dalam mencari nafkah, saya menjual berbagai macam sembako dan kebutuhan rumah tangga, sebelum ada café sawah, pembeli hanya lingkung $R T$ atau desa, tapi semenjak adanya café sawah dan banyaknya pengunjung yang berkunjung ke sini, membawa dampak positif. Pembeli tidak hanya lingkup RT atau Desa tapi juga beberapa pengunjung. Apalagi, saat hari sabtu dan minggu. Banyak pengunjung yang mengujungi toko saya untuk membeli keperluan seperti sandal, kresek, air mineral, snack dan lain lain"

\section{Responden 3. Ibu Matul (Pemilik Homestay):}

"Dulu sebelum ada wisata di desa ini saya hanya hidup sebagai seorang istri yang tidak menghasilkan uang, dan hanya mengandalkan nafkah dari suami. Tapi setelah adanya wisata dan program pengadaan homestay sebagai akomodasi wisata saya memanfaatkan salah satu kamar kosong di rumah dan menjadikannya Homestay sesuai yang dianjurkan desa. Kini meskipun dirumah saja saya bisa memanfaatkan kamar kosong menjadi lebih produktif. Dan tentunya bisa mendapatkan uang tambahan."

\section{Responden 4. Ibu Komariah (Home Industry):}

"Saya adalah seorang istri yang mempunyai usaha kecil kecilan membuat olahan snack dari bahan sayur mayur. Sebelum dijadikan desa wisata saya mengandalkan kenalan dan sosial media untuk memasarkan produk saya. tapi kini dengan adanya desa wisata jangkauan saya dalam memasarkan produk semakin luas, bahkan sekarang saya bisa memperkerjakan beberapa pegawai dalam memproduksi snack ini"

\section{Responden 5. Bapak Sajidin (Peternak Sapi):}

"Saya adalah Seorang Kepala Rumah tangga yang bermata percaharian sebagai petani dan peternak. Dengan adanya desa wisata ini dan program pemberdayaan masyarakat desa. Kerap kali kandang saya di sewa oleh anak anak dari live in untuk dijadikan tempat edukasi peternakan sapi. Mereka belajar memerah dan 
memberi pakan sapi hal ini tentu membantu menambah penghasilan saya selain dari bertani dan berternak".

Menilik hasil wawancara beberapa responden yang peneliti jelaskan diatas Program pemberdayaan masyarakat desa wisata pujonkidul dirasa cukup berhasil karena masyarakat desa yang menjadi lebih mandiri, terampil dalam memanfaatkan kemampuan dan kompetensi mereka sehingga dapat meningkatkan perekonomian para responden.

Atraksi Desa wisata juga perlu mendapatkan perhatian dengan bertambahnya tahun atraksi yang ditawarkan Desa wisata ini juga semakin bertambah hal ini membawa dampak bagi masyarakat setempat terlebih dalam penyerapan tenaga kerja setidaknya 2.000 orang atau hampir $50 \%$ penduduk yang bekerja dan ikut serta menyukseskan program pengembangan desa mulai dari remaja yang masih menganggur ataupun orang tua yang mencari pekerjaan sambilan. ${ }^{7}$ Seperti penelitian yang dilakukan oleh Amelia et al., ${ }^{8}$ dan juga Hidayatullah et al., ${ }^{9}$ dimana pengembangan pokdarwis dapat meningkatkan pendapat masyarakat desa dan membantu promosi wisata yang ada Pemberdayaan masyarakat dilakukan untuk meningkatkan ekonomi lokal ${ }^{10}$ yang dan dan membatu pengembangan usaha masyarakat di sekitar desa wisata tersebut. ${ }^{11}$

\section{KESIMPULAN}

Kesimpulan yang didapatkan dari penelitian ini adalah kegiatan pemberdayaan masyarakat melalui wisata edukasi yang di adakan di desa pujonkidul cukup mampu memberikan dampak kepada masyarakat sekitar. hal tersebut dapat dilihat memalui hasil wawancara responden yang menjelaskan dengan adanya program pengembangan desa melalui pemberdayaan masyarakat yang berarti melibatkan masyarakat dalam prosesnya. Masyarakat sepakat memberikan jawaban yang serupa bahwa perekonomian masyarakat yang terlibat dirasa meningkat setelah terlaksananya program pemberdayaan.

7 Stella Alvianna, “ANALISIS PENGARUH HARGA, PRODUK, DAN KUALITAS LAYANAN TERHADAP KEPUASAN WISATAWAN DI TAMAN WISATA AIR WENDIT KABUPATEN MALANG," Jurnal Pariwisata Pesona; Vol 2, No 1 (2017): Edisi Juni 2017, June 30, 2017, http://jurnal.unmer.ac.id/index.php/jpp/article/view/1263.

${ }^{8}$ Rizka Amelia and Syarif Hidayatullah, "The Effect of Instagram Engagement to Purchase Intention and Consumers' Luxury Value Perception as the Mediator in the Skylounge Restaurant," International Journal of Innovative Research \& Growth 5 (April 29, 2020): 958-66.

9 Syarif Hidayatullah et al., "The Effectivity of ' Pokdarwis' Role on Successfully Marketing of Tourism Village Towards " Mega Tourism : Batu City For The World," International Conferences SDGS 2030 Challenges Dnd Solutions 1, no. 1 (2017).

10 Syarif Hidayatullah et al., "Peran Sistem Informasi Pemasaran, Kualitas Pelayanan Dan Entrepreneurial Marketing Serta Kepuasan Terhadap Loyalitas Generasi Milenial Berkunjung Ke Tempat Wisata," Jurnal Ilmiah Bisnis Dan Ekonomi Asia 14 (February 29, 2020): 74-83, https://doi.org/10.32812/jibeka.v14i1.184.

11 Amelia and Hidayatullah, "The Effect of Instagram Engagement to Purchase Intention and Consumers' Luxury Value Perception as the Mediator in the Skylounge Restaurant." 


\section{REFERENSI}

Alvianna, Stella. "ANALISIS PENGARUH HARGA, PRODUK, DAN KUALITAS LAYANAN TERHADAP KEPUASAN WISATAWAN DI TAMAN WISATA AIR WENDIT KABUPATEN MALANG." Jurnal Pariwisata Pesona; Vol 2, No 1 (2017): Edisi Juni 2017, June 2017. http://jurnal.unmer.ac.id/index.php/jpp/article/view/1263.

Amelia, Rizka, and Syarif Hidayatullah. "The Effect of Instagram Engagement to Purchase Intention and Consumers' Luxury Value Perception as the Mediator in the Skylounge Restaurant." International Journal of Innovative Research $\mathcal{E}$ Growth 5 (April 29, 2020): 958-66.

Hidayatullah, Syarif, Ike Rachmawati, Eko Aristanto, Abdul Waris, and Ryan Patalo. "Peran Sistem Informasi Pemasaran, Kualitas Pelayanan Dan Entrepreneurial Marketing Serta Kepuasan Terhadap Loyalitas Generasi Milenial Berkunjung Ke Tempat Wisata." Jurnal Ilmiah Bisnis Dan Ekonomi Asia 14 (February 29, 2020): 74-83. https:/ / doi.org/10.32812/jibeka.v14i1.184.

Hidayatullah, Syarif, Ike Kusdyah Rachmawati, Umu Khouroh, and Irany Windhyastiti. "The Effectivity of " Pokdarwis ' Role on Successfully Marketing of Tourism Village Towards " Mega Tourism: Batu City For The World." International Conferences SDGS 2030 Challenges Dnd Solutions 1, no. 1 (2017).

Moleong, Lexy J. Metodologi Penelitian Kualitatif, Ed. Revisi/ Moleong. Bandung: Remaja Rosdakarya, 2010.

Mulyadi, Mohammad. "PERAN PEMERINTAH DALAM MENGATASI PENGANGGURAN DAN KEMISKINAN DALAM MASYARAKAT." Jurnal Kajian 21, no. 3 (2016). https:/ / doi.org/https:/ / doi.org/10.22212/kajian.v21i3.776.

Suwantoro, Gamal. Dasar-Dasar Pariwisata. Jakarta: ANDI, 2004. https:/ / onesearch.id/Record/IOS7783.ai:slims-5288.

Trisnawati, Aditya Eka, Hari Wahyono, and Cipto Wardoyo. “Pengembangan Desa Wisata Dan Pemberdayaan Masyarakat Berbasis Potensi Lokal." Jurnal Pendidikan: Teori, Penelitian, Dan Pengembangan; Vol 3, No 1: JANUARI 2018DO 10.17977/Jptpp.V3i1.10356 ， January 1, 2018. http://journal.um.ac.id/index.php/jptpp/article/view/10356.

Wulandari, Ayu Purnami. "Pemberdayaan Masyarakat Desa Dalam Upaya Peningkatan Kesejahteraan Keluarga Melalui Pelatihan Pembuatan Sapu Gelagah Di Desa Kajongan Kecamatan Bojongsari Kabupaten Purbalingga." Universitas Negeri Yogyakarta, 2015.

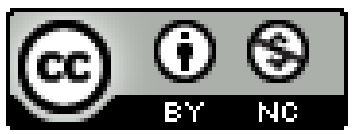

(C) 2021 by the authors. Submitted for possible open access publication under the terms and conditions of the Creative Commons Attribution-NonCommercial 4.0 International License (CC BY NC) license (https://creativecommons.org/licenses/by-nc/4.0/). 